\title{
Correction to: Effect of decay on shear performance of dowel-type timber joints
}

\author{
Kei Sawata ${ }^{1}$ Takanobu Sasaki ${ }^{2} \cdot$ Shuichi Doi ${ }^{3} \cdot$ Yasuo lijima $^{2}$
}

Published online: 27 November 2018

(c) The Author(s) 2018

\section{Correction to: J Wood Sci (2008) 54:356-361 https://doi.org / https://doi.org/10.1007/ s10086-008-0963-7}

The article Effect of decay on shear performance of doweltype timber joints, written by Kei Sawata, Takanobu Sasaki, Shuichi Doi and Yasuo Iijima, was originally published electronically on the publisher's internet portal (currently SpringerLink) on 7 June, 2008 without open access. With the author(s)' decision to opt for Open Choice the copyright of the article changed on 28 November 2018 to () The Author(s) 2018 and the article is forthwith distributed under the terms of the Creative Commons Attribution 4.0 International License (http://creativecommons.org/licenses/ by/4.0/), which permits use, duplication, adaptation, distribution and reproduction in any medium or format, as long as you give appropriate credit to the original author(s) and the source, provide a link to the Creative Commons license and indicate if changes were made.

Open Access This article is distributed under the terms of the Creative Commons Attribution 4.0 International License (http://creativeco mmons.org/licenses/by/4.0/), which permits unrestricted use, distribution, and reproduction in any medium, provided you give appropriate credit to the original author(s) and the source, provide a link to the Creative Commons license, and indicate if changes were made.
The original article can be found online at https://doi.org/10.1007/ s10086-008-0963-7.

Kei Sawata

ksawata@for.agr.hokudai.ac.jp

1 Graduate School of Agriculture, Hokkaido University, N9 W9, Kita-ku, Sapporo 060-8589, Japan

2 Institute of Wood Technology, Akita Prefectural University, Noshiro 016-0876, Japan

3 Graduate School of Life and Environmental Sciences, University of Tsukuba, Tsukuba 305-8572, Japan 